\title{
Study On The Economic Strategy Of Shaanxi Development
}

\author{
Huijie Yang \\ School of Xi'an Peihua University \\ Xi'an 710125, China \\ e-mail:395436613@qq.com
}

\begin{abstract}
The study of the real economy is a hot topic among experts and scholars. The study of industrial structure adjustment has resulted in the growth of economy, however the adjustment on industrial supply side structure has little effect on the real economy. This paper used, methods of literature review, mathematical statistics, logic reasoning method for studying. on the basis of the current situation of industrial structure in Shaanxi province, This paper finds out the deficiency of industrial structure, The research emphases on the how the Industrial structure change affected the real economy, and thus concluded that industrial structure adjustment supply side plays an important role on the real economy in Shaanxi province.
\end{abstract}

Keywords-Real Economy; Industrial Structure; Sustainable Development

I. THE RELATIONSHIP BETEEN INDUSTRIAL STRUCTURE AND ECONOMIC GROWTH, VIRTUAL ECONOMY AND REAL ECNOMY

\section{A. Research on the real economy}

The study of real economy in foreign countries dates back to the 1970s. Etzioni Mitai (1980) proposed "reindustrialization" after studying the phenomenon of slowing economic growth in the United States in the 1970s. Chang Yu Zhang (2011) put forward the strategy of "industrialization" has given priority to advanced manufacturing to build the real economy in the post-crisis era. The United States expects to develop its competitive advantage by turning attention on the real economy. After analyzing the current situation of the manufacturing industry China the United States should seize an opportunity to expand oversea mergers and acquisitions. Besides ,mastering advanced core technology is one of the important channels to expand manufacturing industry in China. Zhao gang (2010) stressed the importance of developing advanced manufacturing and reconstructing the real economy by analyzing the impact of the specific policy measures about "reindustrialization" in the United States.

\section{B. Research on virtual economy}

The term "virtual economy" comes from the United States in the early 1990s, which refers that the financial market is dominated by the stock market. The virtual economy mainly includes real estate market and financial market. Siwei Cheng (1999) believed that the virtual economy was the economy of money makes money . Xiao Qin (2000) on the basis of Mr.
Cheng's, Xiao Qin (2000) gave a more detailed definition about the virtual economy. He thought that virtual economy was the expansion on credit after the form of the financial asset .Furthermore, activity under virtual economy was not associated with the real economy.

\section{Economic growth}

Economic growth refers to the continuous increase of national economic aggregate or per capita output of a country or region within a certain period of time. Now speak of economic growth is refers to the per capita gross domestic product (GDP) or gross domestic growth, the corresponding also developed a lot of research on economic growth factors and how to achieve sustainable economic growth theory (B. Herrick, 1983).

\section{Industrial structure}

Generally speaking, structure refers to the collocation and arrangement of the parts of a system or whole. At the same time, the industrial structure refers to the proportion of each industry in the overall economic system within a certain region and the technical and economic relationship between them ( Tao Liu, 2013).

\section{E. the dialectical relationship between industrial structure and economic growth}

Industrial structure and economic growth can be seen as different aspects of economic development, and there is a close relationship between them. First, the output structure is an important reason to promote economic growth, such as labor, capital and technological progress. Second, when the economy develops to a certain stage, the original economic equilibrium will inevitably be broken, resulting in corresponding changes in the industrial sector pattern. At this point, it seems reasonable that the industrial structure which can promote economic development can meet the further development of the economy and even become an irrational structure that impedes economic growth. This paper attempts to collect literature on "research on the influence of supply-side structural reform on the real economy", but no direct statement is made. However, this paper sets out from the literature statement of the real economy, fictitious economy, industrial structure and economic growth to clarify the industrial structure adjustment, reduce the proportion of fictitious economy and promote economic growth. Leading to the development of the real economy. 


\section{F. The dialectical relationship between virtual economy and real economy}

1) Virtual economy is dependent on the real economy

Virtual capital is directly in the production field, and is directly used for consumption. It is in the middle stage between production and consumption. It is determined by production. Therefore, the virtual economy of virtual capital as the sports object is determined by the real economy which is produced as the exercise mode. The real economy is the foundation of the virtual economy.

a) The real economy is the basis for the generation, development and expansion of virtual economy

The history of the virtual economy is closely related to the real economy. The virtual economy emerged from the day of birth to reduce the transaction cost of the real economy and improve the operation efficiency of the real economy. The real economy is the foundation of virtual economic innovation.

b) The real economy is the basis of virtual economic innovation

The condition of the real economy is the foundation of the healthy operation of the fictitious economy, the real economy is in good condition, and the operation of the virtual economy has a solid material foundation. Otherwise, if the real economy could no longer sustain conveying the whole virtual economy required growing income water at ordinary times, so the operation of the virtual economy will be affected, the virtual economy is likely a major crisis.

2) The virtual economy of moderate scale can promote the development of real economy

Virtual economy has "wealth effect" to pull real economy growth. The virtual economy promotes the growth of GDP in a certain way.

a) virtual economy facilitates the accumulation of capital and capital formation of the real economy

b) The virtual economy mobilizes savings for investment and promotes capital accumulation and capital formation of the real economy

3) Virtual economy is conducive to optimizing the allocation of resources and improving the allocation efficiency

a) The virtual economy will improve the efficiency of resource allocation through financing

b) Virtual economy improves resource allocation efficiency by providing liquidity

c) Virtual economy can improve the efficiency of resource allocation by transferring information

4) The virtual economy is conducive to the diversification of the operation risk of the main market players and lower transaction costs

Virtual economic activity can reduce the cost of transaction and reduce the barriers to economic activity by alleviating the frictions in economic life, thus producing more material wealth. For example, since the 1970 s, international oil spot trading has grown rapidly and international oil prices have started to fluctuate wildly. The rise of international energy is a heavy burden on China's economic development. According to the calculation, the change in the world oil price per barrel will affect the import of RMB 4.6 billion, directly affecting the fluctuation of 0.043 percentage points. If the futures market is perfect, can to preservation of oil, we can avoid oil price fluctuations on the influence of the CAP, on the other hand, use the function of the futures market, only by oil that a virtual economy, would indirectly created the 0 . $043 \%$ of CDP. It can be seen that the virtual economy further enhances its use efficiency through the optimized allocation of capital, thus creating new wealth and promoting the growth of the real economy.

\section{CURRENT SITUATION AND EXISTING PROBLEMS OF THE REAL RCONOMY IN SHAANXI PROVINCE}

According to the 2014 statistical yearbook report of Shaanxi province, the composition of the added value of the industry shows that the 2014 growth rate is $9.7 \%$ higher than that of 2013. The financial sector grew by $17 \%$. The real estate industry grew by 7.8\%; Construction growth was $11.8 \%$; Industrial growth of $10.8 \%$; The industrial structure is not reasonable, the financial industry, real estate industry and the construction industry are developing too fast, and the speed of industrial development is obviously insufficient, so the industrial structure must be adjusted. The ratio of primary industry, secondary industry and tertiary industry is 1:6.15:4.20. We should increase the development of agricultural first industry, especially in the development of green products such as tea production. In terms of the structure of investment in fixed assets, the primary industry, secondary industry and tertiary industry ratio of 1:5. 57:11. 32, to reduce the fixed assets in the tertiary industry, the first industry namely agriculture to invest heavily to energy-saving industrial projects, technological transformation projects to increase investment; From the perspective of the structure of fixed asset investment economy, the ratio of state-owned economy, collective economy, other economy and individual economy is $19.18: 1.5: 23.73: 1$, to develop individual economy and collective economy. In the province to build a few more home village, Village Ma Wei yi Village, The party Village, Yuan home Village, parties, rapid growth of the collective economy; Vigorously develop individual economy, namely develop traditional characteristic enterprise. Only when the real economy develops will society settle.

\section{A. Economic aggregate growth is fast and relatively low}

The economic scale of Shaanxi is growing rapidly, but the gap between the total volume and the relatively developed regions is obvious, which needs to be further improved.

\section{B. Economic growth has a deep investment dependency and the overall economic structure needs to be optimized}

According to the spending, according to calendar year in Shaanxi province GDP accounting method to calculate the early reform and opening up, Shaanxi "total capital formation" is far lower than the same period of "the total amount of final consumption", "net outflows of goods and 
services" has been in a negative state, economic growth mainly comes from the consumer driven. Since then, with the rapid growth of investment in economic development, the gap between the two has been narrowing. Until 2010, its total capital formation "first time" at the end of the total consumption ", "investment" instead of "consumption" has become the fastest "carriage" of economic development, economic growth is mainly driven by investment, consumption, and the "net outflows of goods and services" still is in negative state, the economy is "short board" restricting the development of its economy; Since 2011, the total annual capital formation of Shaanxi has continued to accelerate, and the contribution of investment to economic growth has continued to increase. Statistics show that the proportion of fixed assets investment as a proportion of GDP rose from $40.56 \%$ in 2010 to $61.86 \%$ in 2015 , up from $40.56 \%$ in 2010 , and even up to $67.50 \%$ in 2016 . The growing reliance on investment for economic growth has become a fact of life. Therefore, Shaanxi should continue to strengthen the optimization and adjustment of the regional economic structure, and realize the combination of consumption, investment and net inflow of "troika" to promote its balanced economic development.

\section{The characteristics of tourism, education and high-tech cities are obvious, and the rationalization of \\ inter-industrial structure is slow}

As a new innovation province in China, Shaanxi tourism, education and high-tech industries have developed rapidly. In 2014, the GDP of the first industry accounted for $8.81 \%$ of GDP. The GDP of the second industry is $54.19 \%$ of GDP; The GDP of the tertiary industry accounts for $37.00 \%$ of Shaanxi GDP. The outstanding problem is that the first industry lags behind and the agricultural population accounts for $60 \%$ of the whole province. The per capita GDP of agriculture is too low, which has severely affected the pace of Shaanxi's catch-up with the advanced provinces. The second industry has the highest proportion in the real economy of Shaanxi, which has been the first dominant position, but the growth rate is not obvious. The economic pull of Shaanxi is not big; In the same period, Shaanxi's tertiary industry (excluding finance and real estate) has maintained an accelerated growth rate, which has nearly quadrupled in six years. There is an imbalance between industries.

\section{Regional economic development is unbalanced and the urban and rural areas are under a lot of pressure}

At present, the "two hours economic circle" (hereinafter referred to as "two circles") in Shaanxi is clearly ahead of the rest of the northwest in terms of economic foundation, urban construction and personnel training. But uneven development; In order to develop the "xi 'an", the GDP contribution of other regions to Shaanxi is not sufficient. In order to catch up with Sichuan and Guangdong, Zhejiang, Jiangsu and other provinces, it also needs to work hard.

\section{MEASURES TO DEVELOP THE REAL ECONOMY IN SHAANXI}

The core of the reform of the "supply side" lies in the optimization of industrial structure adjustment, improve the total factor productivity, and deal with dialectical relationship between virtual economy and real economy, so as to promote the development of the real economy. And structural adjustment, promote growth is the premise of must be present industry situation and its effect on economic growth and have a good grasp, so in order to understand the reality, based on the Douglas production function, the input key elements of the efficiency factors and the industrial structure, build the corresponding panel data analysis model, the relevant conclusions, and found that the industrial structure on economic growth in the new period of weak links, and can find out from the aspects of industrial structure adjustment in Shaanxi province to promote sustained economic growth. There are two main points: first, based on the analysis of industrial structure in Shaanxi province and its leading industry, on the basis of deviation share analysis around the city, Shaanxi province is analyzed in the process of "twelfth five-year" economic growth is the industrial structure, location advantages and disadvantages, the advantages and disadvantages to adjust measures to local conditions around the city of Shaanxi province to promote economic growth has the very good guidance. Second, based on the panel data of Shaanxi province, the industrial structure as the system factors into the production function, using the panel data of Shaanxi province, the industrial structure of Shaanxi province was discussed from the Angle of production since 2010's impact on economic growth and the effect on the efficiency of the labor and capital factors, further on how to promote economic growth in Shaanxi province put forward some policy Suggestions.

\section{A. Increase the total amount of investment and balance the development level of various industries}

1) Improve the structure of the financial market and promote the transformation of the real economy

a) Accelerate the development of securities insurance industry

As the overall financial structure of the whole country, the securities and insurance industry, which usually serves as one of the three pillars of the regional financial system, has far less assets and financial influence in Shaanxi than the banking industry. As one of the most important part in the financial system, promote Shaanxi securities industry and insurance industry rapid development, on the one hand can make up for the bank on the business areas, meet the financial needs of Shaanxi economy diversification, on the other hand can improve Chongqing existing financial structure, reduce dependence on banking entity economy development, weaken the bank-dominated financial have credit problems such as resource allocation is too conservative, played to the capital market and efficient fund-raising ability and economic diversification, etc, meet the entity in the process of economic 
transformation development financing and risk transfer and other requirements.

\section{b) Actively cultivate new financial institutions}

In advancing the Shaanxi financial structure to improve, give play to the role of the three pillar financial market at the same time, should actively cultivate all kinds of new type of financial institutions, as a useful supplement, financial market with capital market gradually build an efficient system of direct financing, meet the diversification of the real economy, especially from small and medium-sized enterprise financing needs.

2) Cultivate regional financial institutions and create financing advantages for local enterprises

Although Shaanxi has established bank of The farmers, bank of xi 'an, northwest Shaanxi securities, Shaanxi international trust, a relatively large scale of local financial institutions, such as the overall number still less, to support domestic enterprises co., LTD. For local governments, should be in line with the principles of risk control, the cancellation of regional small and medium-sized financial institutions especially non-state financial institutions policy discrimination, limit the monopoly privilege of large financial institutions, to build a equality of opportunity, the market environment of fair competition.

\section{B. Guide the rational allocation of financial resources and ensure the overall development of urban and rural areas}

We will adjust the investment scale of the financial sector, real estate and construction industries to expand the proportion of industrial and agricultural investment. Appropriate control of the investment scale of tertiary industry; To build a financial services system that is compatible with urban and rural development. Agricultural bank and qinong bank should continue to increase their support to rural economy, and guarantee that there is no less than a fixed proportion of the annual new loans to solve the problem of "three farmers". The agricultural trust society should adhere to the market positioning of "agriculture, rural and rural" services, and play its role as the main force of rural finance. Secondly, develop a guided regional tilt policy to guide the allocation of social resources to backward areas. Finally, financial institutions should be encouraged to innovate financial services and develop financial products adapted to local financing features. Through systematic arrangement, we strive to develop faster in the backward region of the financial support area, balance the regional development pattern, narrow the urban-rural gap in Shaanxi , and promote the overall development of urban and rural areas.

\section{Strengthen macro-control of the real estate market and guide the healthy development of the real estate market}

Facing the current real estate market is facing overheated investment, house prices are too high, the real estate industry and the real economy development not harmonious, The government should continue to deepen the market-oriented reform of the real estate industry, improve the real estate market access system, breaking the developer market monopoly, encourage housing construction market diversification; Reform the land transfer system and reduce the local government's reliance on land finance; The land property right in rural areas is clearly defined, and the market allocation of urban and rural land is realized. Should be resolutely curb speculative demand in the real estate market at the same time, through individual housing information nationwide network, improve the down-payment, and loan interest rates and other technical and financial means, limit suite to buy more, the more suites holders a property tax, property tax, raise the cost of the speculation. In addition, it is necessary to intensify the building of affordable housing, affordable housing, economy applicable room system design, to ensure the benefit object for low and middle income earners, reduce housing demand as well as protect the housing fair right of many low and middle income earners.

\section{CONCLUSION}

General secretary Xi Jinping pointed out in his speech at the opening ceremony of the October 18, 2017, that we should implement the concept of new development and build a modern economic system. Deepening supply-side structural reform; Accelerate the construction of an innovative country; To implement the strategy of rural revitalization; To implement regional coordinated development strategy; Accelerate the improvement of the socialist market economy; We will promote a new pattern of overall openness. We in Shaanxi province should seize the opportunity, deepen the reform of the supply side structural, increase agricultural investment in primary industry namely, guarantee rural revitalization strategy implementation, thus increasing the first industrial GDP growth; We will deepen new economic growth areas in northern Shaanxi and southern Shaanxi, and implement the implementation of the "great xi 'an circle", bringing the total GDP to more than 12 .

\section{REFERENCES}

[1] Cheng Siwei. Virtual economic exploration [J]. Journal of nankai (philosophical social science edition), 2003 (2) :23-28

[2] Li Xiaoxi, Yang Lin. Further discussion on the connotation of virtual economy [J]. Southwest finance, 2007 (11):6-10

[3] Guan Xiaoming. Analysis of structural transformation and potential growth rate of China $[\mathrm{J}]$. Financial theory and practice, 2014 (4) :35-41

[4] Pei Zhifeng. Empirical study on the potential output of China based on production function method [D]. Jilin university, 2014, 4

[5] Party Yao, Liu Sifeng, Wang Qingfeng et al. Regional industrial structure optimization theory and practice $[\mathrm{M}]$. Beijing: science press, 2009 (3-4)

[6] Liu tao. Relationship between economic growth and industrial structure changes [M]. Beijing: science press, 2013

[7] Zhao gang. The United States sends out a signal to the real economy [N], economic reference, 2010-04-15

[8] Ma zhigang. Warning of backflow in western manufacturing $[\mathrm{N}]$, economic daily, 2013-04-26 (6) 